\title{
Incidence of Fracture in Single Ceramic Crowns in Patients with Chronic Tooth Wear: A Clinical Follow-up
}

\author{
Incidencia de Fractura en Coronas Cerámicas Únicas en Pacientes \\ con Desgaste Dental Crónico: Un Seguimiento Clínico
}

\begin{abstract}
Guilherme da Rocha Scalzer Lopes; Ana Amelia de Faria Viana²; Vandeberg Diniz; Jefferson David Melo de Matos ${ }^{1}$; Valdir Cabral Andrade ${ }^{3}$; Marco Antonio Bottino'; Renato Sussumo Nishioka'; Fabio Matos Chiarelli"; Alfredo Carlos Rodrigues Feitosa ${ }^{5}$ \& Selva Maria Gonçalves Guerra ${ }^{5}$
\end{abstract}

LOPES, G. R. S.; VIANA, A. A. F.; DINIZ, V.; MATOS, J. D. M.; ANDRADE, V. C.; BOTTINO, M. A, NISHIOKA, R. S.; CHIARELLI, F. M.; FEITOSA, A. C. R. \& GUERRA, S. M. G. Incidence of fracture in single ceramic crowns in patients with chronic tooth wear: a clinical follow-up. Int. J. Odontostomat., 15(1):102-110, 2021.

ABSTRACT: The aim of this study was to identify the incidence of fractures in single crowns placed in individuals with chronic tooth wear. The sample selection was performed based on the evaluation of 218 patient records rehabilitated with single crowns placed by the same professional from a private clinic. After exclusion criteria, 43 individuals (18 males and 25 females) were included and a total of 112 single crowns distributed in both jaws. Three ceramic systems were evaluated: 34 feldspathic all-ceramic, 38 metal-ceramic with a core in gold electropositive alloy, and 40 In-Ceram Alumina. The intraoral photograph analysis adopted a diagnosis method of tooth wear according to the morphological variations of the teeth. Of the 112 crowns evaluated, 47 were placed in male and 65 in female patients, aged between 21 to 74 years (mean 27.5 years old). The variables gender $(p=0.83)$, presence of chronic tooth wear $(p=0.91)$, ceramic system $(p=0.24)$ and crown location $(p=0.86)$ did not present a statistically difference. However, the variables pulp vitality $(p=0.04)$ and survival time $(p=0.01)$ presented a statistically significant difference. The evaluated ceramic systems can be considered as alternatives of restorative material, even in individuals with clinical characteristics suggestive of chronic tooth wear.

KEY WORDS: tooth crown, prosthodontics, risk factors.

\section{INTRODUCTION}

With the improvement in adhesive dentistry, metal-free ceramic systems were developed in response to this growing concern with aesthetics and an ideal of biocompatibility (Campos et al., 2016). Metal-free ceramics were initially represented by conventional feldspathic ceramics, and later by reinforced ceramic systems (de Matos et al., 2020). Metal-free ceramic crowns present a number of other desirable intrinsic characteristics such as compressive and abrasion resistance, color stability, radiopacity, chemical stability, coefficient of thermal expansion close to the tooth structures and excellent potential to mimic the appearance of natural teeth as the main materials in restorative dentistry (Erpenstein et al., 2000). However, they can present catastrophic fractures when the applied stresses reach the resistance of the material because they are an inelastic material (Cehreli et al., 2011).

The clinical decision for one ceramic system should be guided by clinical studies. There are longitudinal clinical studies which evaluate the perfor-

\footnotetext{
${ }^{1}$ Department of Dental Materials and Prosthodontics, São Paulo State University (Unesp), Institute of Science and Technology, São José dos Campos - SP, Brazil..

${ }^{2}$ Department of Dental Clinic, Federal University of Espírito Santo (UFES), Vitória - ES, Brazil.

${ }^{3}$ Department of Dentistry, Federal University of Juiz de Fora (UFMG), Governador Valadares - MG, Brazil.

${ }^{4}$ DepartmentofDentistry, Rede de Ensino Doctum(DOCTUM), Serra - ES, Brazil.

${ }^{5}$ Department of Dentistry, Federal University of Espírito Santo (UFES), Vitória - ES, Brazil.
}

Received: 2020-06-06 Accepted: 2020-09-21 
LOPES, G. R. S.; VIANA, A. A. F.; DINIZ, V.; MATOS, J. D. M.; ANDRADE, V. C.; BOTTINO, M. A, NISHIOKA, R. S.; CHIARELLI, F. M.; FEITOSA, A. C. R. \& GUERRA, S. M. G. Incidence of fracture in single ceramic crowns in patients with chronic tooth wear: a clinical follow-up. Int. J. Odontostomat., 15(1):102-110, 2021.

mance of these materials when submitted to real loads required in the buccal environment (Pjetursson et al., 2007; Peixoto et al., 2019). The mechanical stresses generated in the buccal environment may reach the resistance curve of these materials, which means that the restorations will be subject to accumulative damage of each material is reached. Thus, fractures in ceramic single crowns can be induced by local and/or individual factors which are difficult to reproduce in mechanical laboratory tests (Bayne, 2007; Campos et al., 2020).

Among these factors is the observation of sociodemographic characteristics and multifactorial causes, which can determine different patterns of tooth wear prior to initiating restorative treatment (van't Spijker et al., 2007). Emphasis on these clinical signs of tooth wear is due to the high prevalence of this condition in the population, including those with advancing age and teeth maintenance by individuals, as in situations suggestive of dental attrition (Young, 2001).

However, other forms of parafunction closely associated with the wear of dental structures should not be ignored by dental surgeons, as well as their potential contributing factors in stomatognathic system disorders and even restorative failures (Machado et al., 2007). In this way, a partial loss in the tooth structure and the procedures involved in its prosthetic restoration encourage development of long term clinical research (Della Bona \& Kelly, 2010; Cehreli et al.).Despite the flexural strength in laboratory tests shows different values among the analyzed materials. The clinical performance of these restorative materials may be similar even in patients with chronic tooth wear.

In view of the above, this study consisted of a longitudinal retrospective observation (120 months) implementing a quantitative approach using a series of cases originated in a private dental clinic in Vitória, ES. Thus, the aim of this study was to identify the incidence of catastrophic fractures in prosthetic single crowns made in different ceramic systems and to evaluate their clinical performance in patients with chronic tooth wear.

\section{MATERIAL AND METHOD}

This retrospective study with cross-sectional design was conducted in accordance with the Helsinki declaration of human studies and Resolution 466/12 of the National Health Council after approval by the Human Research Ethics Committee (CEP) under No. 120/10(attachment A). The sample selection was performed based on an evaluation of 218 patient records, rehabilitated with single crowns installed between 1999 and 2009 by the same team of professionals from a private clinic in the city of Vitória ES, Brazil, all following the same clinical protocol.

Therefore, only patients with complete clinical, radiographic and photographic documentation, patients aged over 18 years old, minimum of 24 teeth, treated by the same team of professionals, with at least one prosthetic single crown with inter-occlusal contact between the crown and antagonist were recruited for the sample.

The following prospective participants were excluded from the study.

a) Individuals who did not meet the inclusion criteria.

b) Individuals who were undergoing orthodontic treatment.

c) Individuals who used a removable partial prosthesis, a 3-unit fixed partial prosthesis and/or removable total prosthesis.

d) Individuals who were treated with dental implants.

Once the data review was completed, the selected patients were contacted over the telephone and invited to participate in the study. Those who agreed to participate were scheduled for clinical evaluation and also had radiography images and intraoral photography taken at a specialized center. The patients were informed about the proposal of the study, its risks and benefits and then asked to sign the Informed Consent Term before beginning the clinical examination. An update was also performed on the personal data of the patients and those related to general health, confirming that they remained within the inclusion criteria.Finally, 43 individuals were included and a total of 112 single prosthetic crowns distributed in the anterior and posterior of both jaws.

Clinical and radiographic examination. Digital intraoral periapical radiographic images of the 112 single prosthetic crowns were obtained in a specialized radiological center for the evaluations to confirm the number of remaining teeth, the presence of antagonist and the pulp vitality among the restored teeth. These periapical radiographs were obtained in JPEG format and evaluated using the Windows Photo Viewer program. 
LOPES, G. R. S.; VIANA, A. A. F.; DINIZ, V.; MATOS, J. D. M.; ANDRADE, V. C.; BOTTINO, M. A, NISHIOKA, R. S.; CHIARELLI, F. M.; FEITOSA, A. C. R. \& GUERRA, S. M. G. Incidence of fracture in single ceramic crowns in patients with chronic tooth wear: a clinical follow-up. Int. J. Odontostomat., 15(1):102-110, 2021.

All patients underwent clinical and radiographic examination performed by a single calibrated professional who was not involved in the surgical and/or prosthetic treatment. An analysis of the prosthetic crowns on whether or not fractures were performed through clinical and photographic exams at the time of data collection, as shown in Figure 1.

Facial and intraoral photographs for the digital photographic collection of these individuals were performed at the time of the initial clinical evaluation of each patient. To do so, a Nikon D100 digital camera was used with a lens with a focal distance of $105 \mathrm{~mm}$ using dental mouth openers and metal mirrors for oral photographs. These images were used to find retrospective information at the beginning of the prosthetic restorative treatment, being adopted for to analyze the presence or absence of clinical signs of chronic destructive tooth wear and ceramic cover fractures recorded in medical records. The patient records were evaluated in order to collect information regarding the occurrence of previous fractures which culminated in replacing the prosthetic crown, as well as the need to repair the crown from the occurrence of the veneering porcelain chipping.

Individual and clinical characteristics were identified and classified in order to characterize this series of cases. Sociodemographic characteristics and the tooth wear pattern observed among the patients were analyzed to determine the individual variables. The clinical subgroups could be classified according to the tooth location, pulp vitality, the ceramic system and the date of the ceramic crown placement.

Intraoral photograph analysis was adopted for this study to diagnose the tooth wear. This strategy was pointed out by Johansson et al. (2008), as capable of identifying worn dentition. The photographs enabled performing a static (punctual) analysis of the clinical pattern observed prior to prosthetic rehabilitation.

According to Johansson et al., 4 analysis parameters of morphological variations in tooth wear are indicated in 4 different grades:

Grade 0 - No visible facets in enamel. Occlusal/incisal morphology intact;

Grade 1- Marked wear facets in enamel. Occlusal/incisal morphology altered;

Grade 2 - Wear into dentin. Dentin exposed occlusally/ incisally and/or adjacent to the tooth surface. Occlusal/ incisal morphology changed in shape with height reduction of the tooth;

Grade 3 - Extensive wear into dentin. Larger dentin area $\left(>2 \mathrm{~mm}^{2}\right.$ ) exposed occlusally/incisally and/or adjacent to the tooth surface. Occlusal/incisal morphology totally lost locally or generally. Substantial loss of crown height.

The characterization of an individual included in the group without clinical signs of chronic tooth wear (Grade 0 and 1) and an individual included in the group with clinical signs of chronic tooth wear (Grade 2 and 3) are shown in Figure 2.
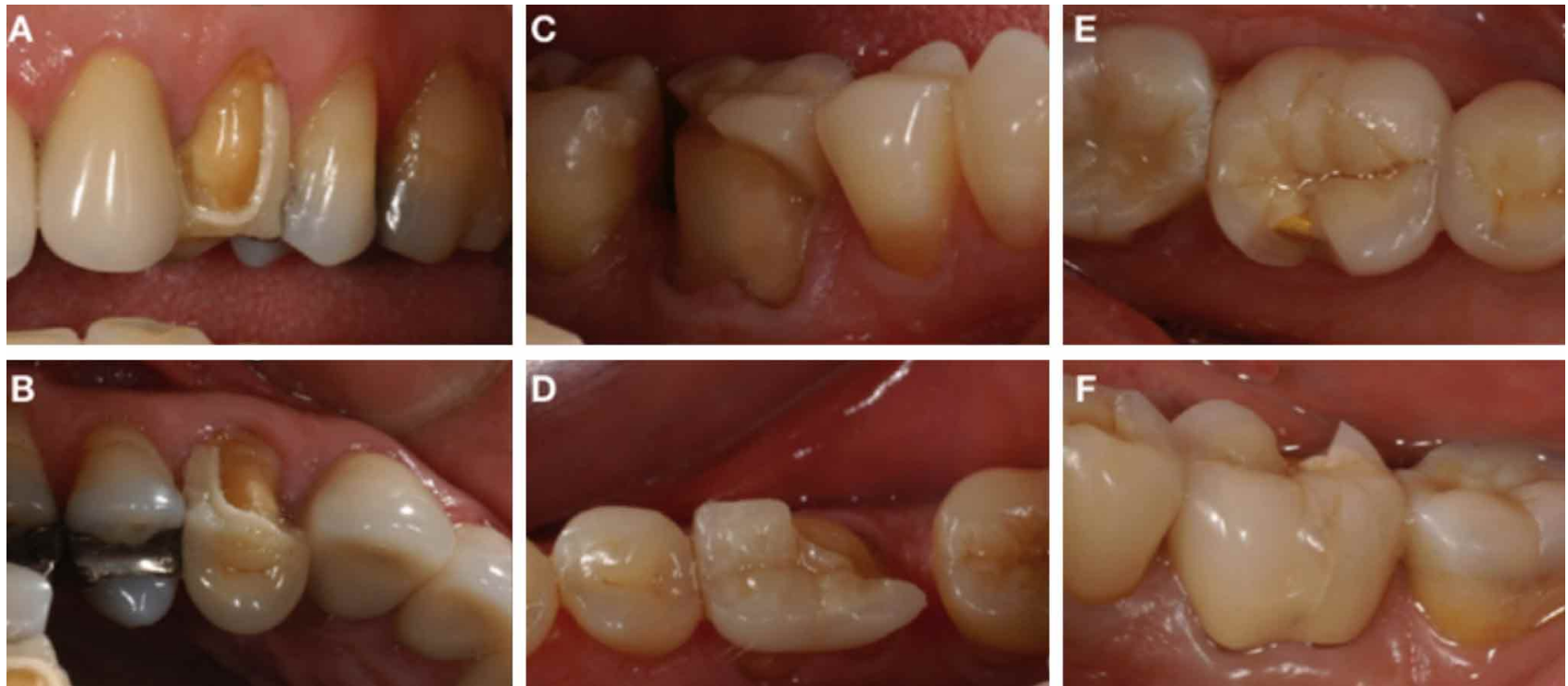

Fig. 1. Fractures in different single crown prosthetic systems. A and B, In-Ceram Alumina crown; C and D, Feldspathic ceramic crown; E and F, Metal-ceramic crown. 

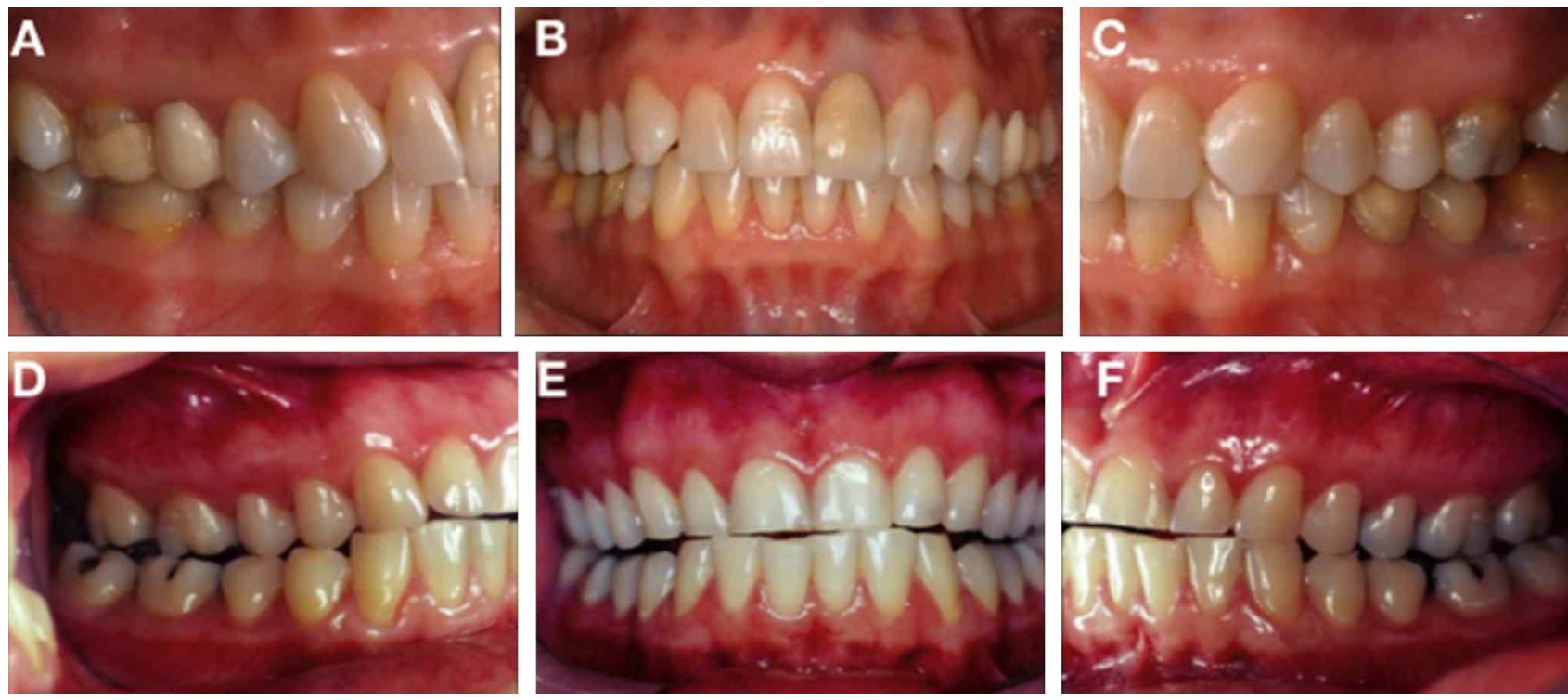

Fig. 2. Individual with no signs of chronic tooth wear (A, B, and C). Individual with signs of chronic tooth wear (D, E, and F).

This study evaluated three ceramic systems with 34 feldspathic all-ceramic crowns (Vita Mark 7, Vita Zahnfabrik, Bad Sackingen, Germany), 38 metalceramic crowns with framework in gold alloy (Omega 900, Vita Zahnfabrik, Bad Sackingen Germany) and 40 all-ceramic In-Ceram Alumina crowns (Vita Zahnfabrik, Bad Sackingen, Germany) composed of aluminum oxide, which is then infiltrated with fused glass, as shown in Figure 3.
The pulp vitality variable was evaluated from the radiographic analysis regarding the presence or absence of radiopaque images of the root-filled canal and/or a periapical radiolucent lesion, while the restored teeth were classified as vital or non-vital at the baseline. The total evaluation time ranged from 23 days to 120 months. During this time, evaluations for the presence or absence of catastrophic fractures were identified and allocated into time stages. These stages were divided
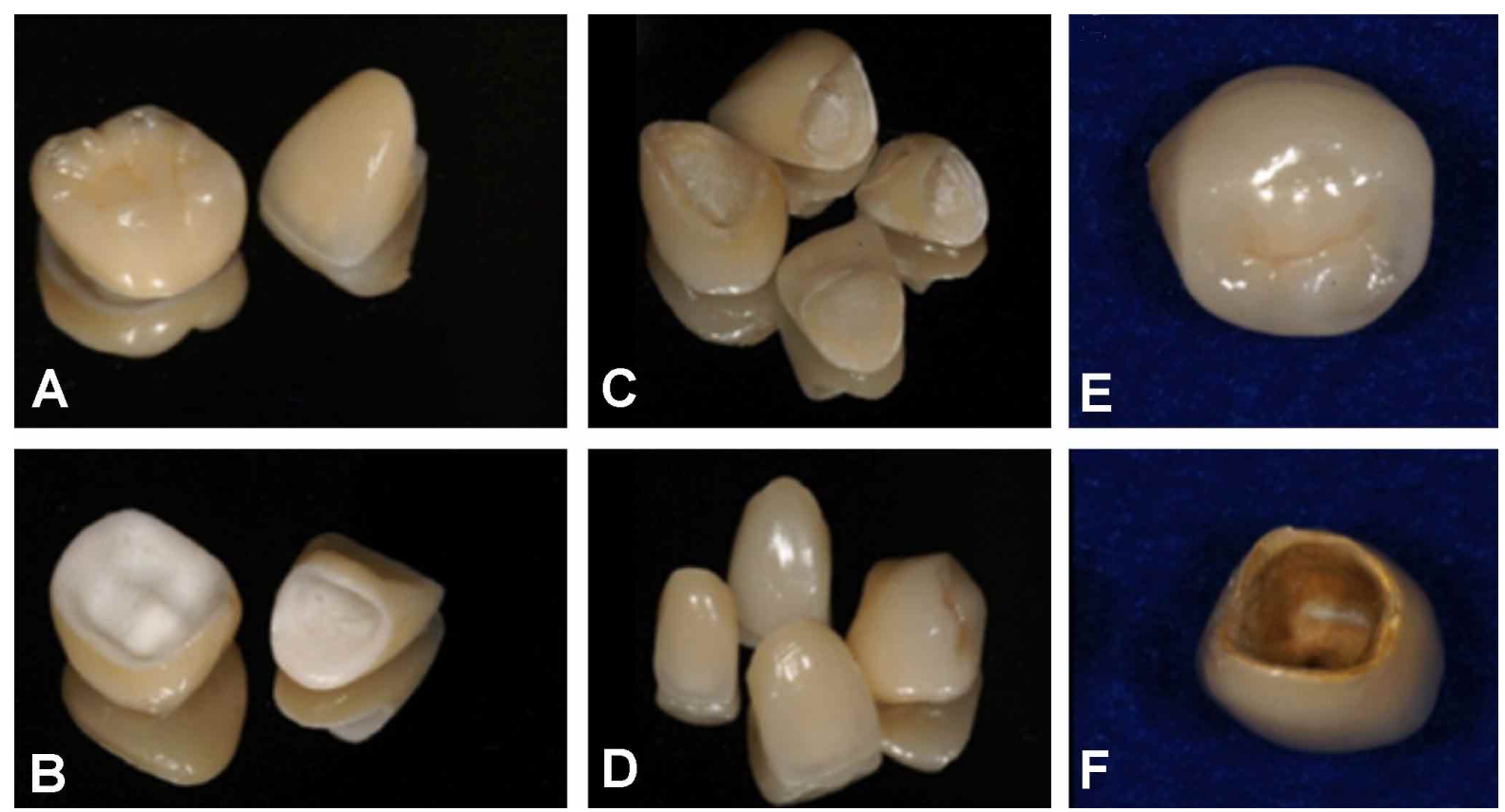

Fig. 3. A and B, In-Ceram Alumina crown (Vita Zahnfabrik, Bad Sackingen, Germany) composed of aluminum oxide; C and D, feldspathic all-ceramic crown (Vita Mark 7, Vita Zahnfabrik, Bad Sackingen, Germany); E and F, metal-ceramic crown (Omega 900, Vita Zahnfabrik, Bad Sackingen Germany). 
LOPES, G. R. S.; VIANA, A. A. F.; DINIZ, V.; MATOS, J. D. M.; ANDRADE, V. C.; BOTTINO, M. A, NISHIOKA, R. S.; CHIARELLI, F. M.; FEITOSA, A. C. R. \& GUERRA, S. M. G. Incidence of fracture in single ceramic crowns in patients with chronic tooth wear: a clinical follow-up. Int. J. Odontostomat., 15(1):102-110, 2021.

according to Marklund et al. (2003), into: until 12 months; from 12 to 24 months; from 24 to 36 months; from 36 months to 48 months; from 48 to 60 months; and from 60 to 120 months.

Statistical analysis. The prosthetic crown was considered as the sample unit in the present study. The fail criteria were a catastrophic fracture of the samples. All the variables related to the crowns were statistically analyzed and the most indicated statistical test was applied according to the type of variable to be tested (categorical or numerical).

In this context, the presence of the fracture crown variable presents two distinct levels (presence or absence). The Chi-Squared test was used when tested with dichotomous variables, and a contingency table was constructed for Chi-squared application when the variable was also presented as polychotomic. A normality analysis was applied (assumption of several parametric tests) in the case of numerical (quantitative) variables, and the Kruskal-Wallis test was adopted according to the result.
Statistical tests were performed in R-project 3.2.0 statistical software (R Core Team, Vienna, Austria). The level of significance established for the tests was $5 \%$, which established a $95 \%$ confidence interval for the presented results, and the power of a statistical test was $80 \%$.

\section{RESULTS}

Of the 112 prosthetic crowns evaluated in 43 individuals ( 18 males and 25 females), 47 were installed in male patients and 65 in female patients, aged between 21 to 74 years (mean 27.5 years old). The variables sex $(p=0.83)$, presence of chronic tooth wear $(p=0.91)$, ceramic system $(p=0.24)$ and crown location $(p=0.86)$ did not present a statistically significant difference regarding the prosthetic crowns, as shown in Table I. The variables pulp vitality $(p=$ $0.04)$ and survival time $(p=0.01)$ presented a statistically significant difference, showing that when there was failure it occurred in the first years of the

Table I. Distribution of the different variables regarding the prosthetic crown.

\begin{tabular}{|c|c|c|c|}
\hline Prosthetic crowns variable & $\mathrm{N}(\%)$ & Fracture ( \%) & $p$-value \\
\hline Number of prosthetic crowns & $112(100 \%)$ & $10(8.9 \%)$ & \\
\hline Sex & & & 0.83 \\
\hline Male & $47(41.9 \%)$ & $5(10.6 \%)$ & \\
\hline Female & $65(58.1 \%$ & $5(7.7 \%)$ & \\
\hline Chronic tooth wear & & & 0.91 \\
\hline Presence & $71(63.4 \%)$ & $7(9.5 \%)$ & \\
\hline Absence & $41(36.6 \%)$ & $3(7.3 \%)$ & \\
\hline Crown Location & & & 0.86 \\
\hline Incisor teeth & $17(15.2 \%)$ & $1(5.8 \%)$ & \\
\hline Canine teeth & $02(1.8 \%)$ & $0(0.0 \%)$ & \\
\hline Pre-molar teeth & $35(31.3 \%)$ & $2(5.7 \%)$ & \\
\hline Molar teeth & $58(51.7 \%)$ & $7(12.0 \%)$ & \\
\hline Crown Ceramic System & & & 0.24 \\
\hline Feldspath ic all-ceramic & $34(30.4 \%)$ & $2(5.8 \%)$ & \\
\hline Metal-ceramic & $38(33.9 \%)$ & $2(5.2 \%)$ & \\
\hline In-Ceram Alumina & $40(35.7 \%)$ & $6(15 \%)$ & \\
\hline Pulp vitality* & & & 0.04 \\
\hline Presence & $40(35.7 \%)$ & $7(17.5 \%)$ & \\
\hline Absence & $72(64,3)$ & $3(4.1 \%)$ & \\
\hline Survival time* & & & 0.01 \\
\hline $0-12$ months & $10(8.9 \%)$ & $2(20.0 \%)$ & \\
\hline 12 - 24 months & $17(15.2 \%)$ & $1(5.9 \%)$ & \\
\hline 24 - 36 months & $17(15.2 \%)$ & $0(0.0 \%)$ & \\
\hline 36 - 48 months & $9(8.0 \%)$ & $0(0.0 \%)$ & \\
\hline 48 to 60 months & $22(19.6 \%)$ & $2(9.1 \%)$ & \\
\hline 60 to 120 months & 37 (33.1\%) & $1(2.7 \%)$ & \\
\hline
\end{tabular}

* Statistically significant difference ( $\mathrm{p}$-value $<0.05)$. 
LOPES, G. R. S.; VIANA, A. A. F.; DINIZ, V.; MATOS, J. D. M.; ANDRADE, V. C.; BOTTINO, M. A, NISHIOKA, R. S.; CHIARELLI, F. M.; FEITOSA, A. C. R. \& GUERRA, S. M. G. Incidence of fracture in single ceramic crowns in patients with chronic tooth wear: a clinical follow-up. Int. J. Odontostomat., 15(1):102-110, 2021.

crown in function, while the crowns in vital teeth were more susceptible to catastrophic failures, as shown in Figures 4 and 5 .

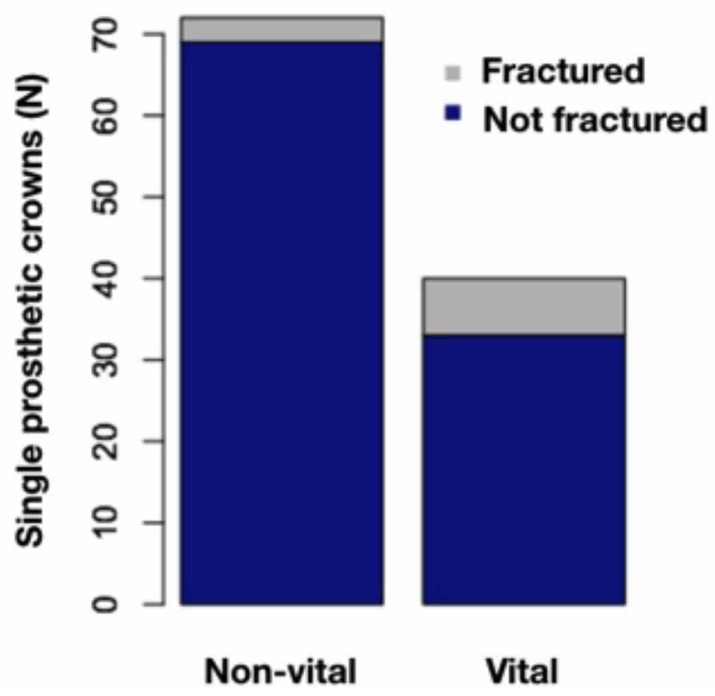

Fig. 4. Catastrophic failures of the prosthetic crowns in vitality and non-vitality teeth.

\section{DISCUSSION}

The present study evaluated a homogeneous group of individuals with a minimum of 24 teeth, with the sample being composed of 43 individuals with 112 prosthetic crowns from 23 days to 120 months of function. This period was considered sufficient for a longitudinal clinical follow-up study in restorative materials (Schwarz et al., 2012). The results of this study showed that the incidence of fractures between the ceramic systems used in the unitary crowns was similarly distributed between the male and female sex. Other studies investigating failures in prosthetic single crowns also present similar results (Schwarz et al.; Lee et al., 2015). However, $10 \%$ of the 47 single crowns in male patients presented fractures; a finding which appears to be attributable to the biting force and occlusal contact area being greater in males than in females (Ferrario et al., 2004).

A total of $63.4 \%$ of the patients' records in this studyshowed clinical signs of chronic tooth wear. These findings corroborate otherstudies in which there is a high prevalence of tooth wear among populations $(\mathrm{Li}$

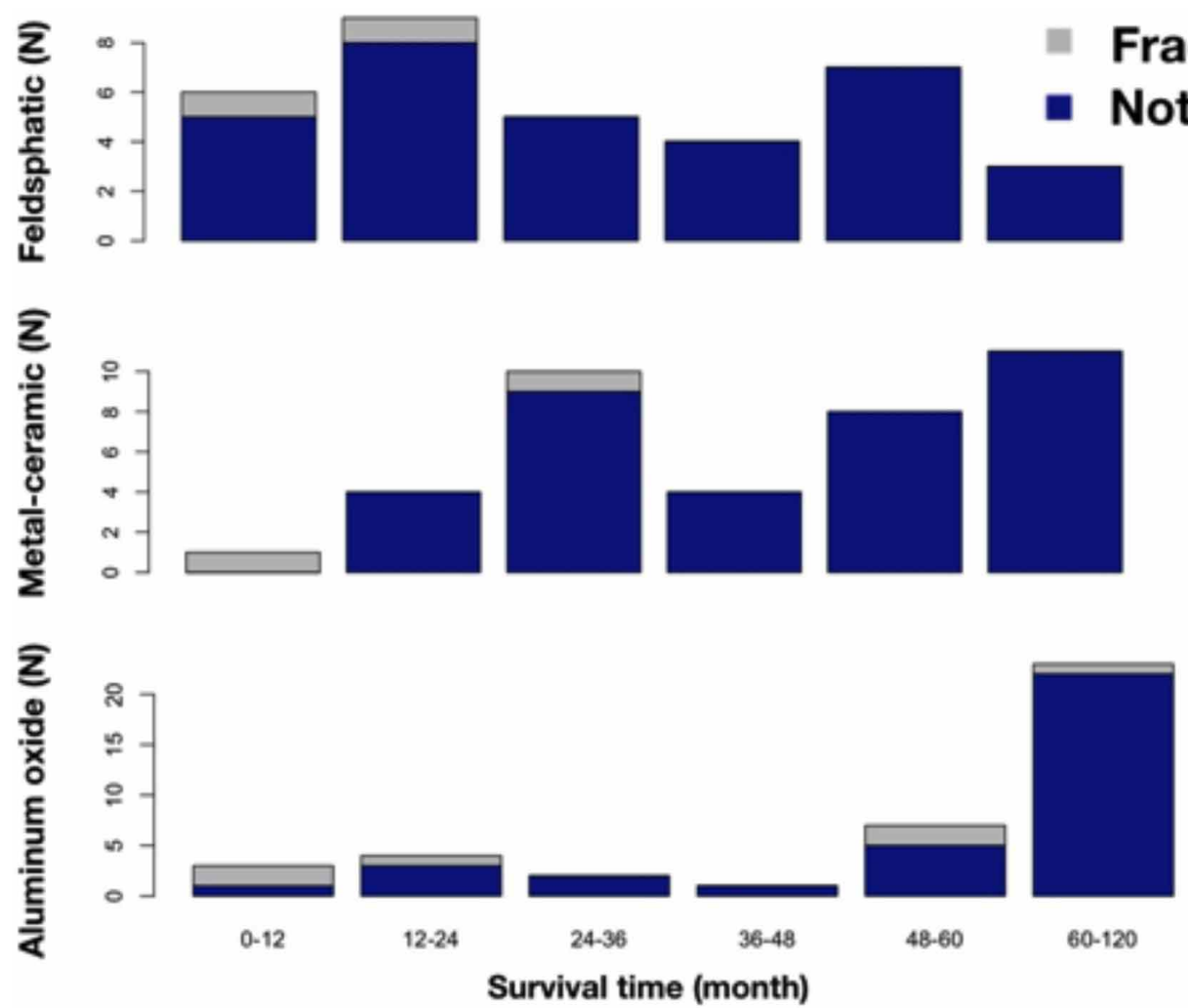

Fig. 5. Survival time of the prosthetic crowns. 
LOPES, G. R. S.; VIANA, A. A. F.; DINIZ, V.; MATOS, J. D. M.; ANDRADE, V. C.; BOTTINO, M. A, NISHIOKA, R. S.; CHIARELLI, F. M.; FEITOSA, A. C. R. \& GUERRA, S. M. G. Incidence of fracture in single ceramic crowns in patients with chronic tooth wear: a clinical follow-up. Int. J. Odontostomat., 15(1):102-110, 2021.

et al., 2019; Zhang et al., 2015). The diagnosis in this study was made by observing intraoral photographs recorded before the beginning of the restorative treatment. This information was valuable for stratifying the observation groups because this was a longitudinal retrospective study. This same method has also been proposed by others as one of the available resources among the clinical identification methods of tooth wear (Telles et al., 2006). Other methods can be used for diagnosing tooth wear and even for analyzing the severity of damage to dental surfaces (Verrett, 2001; Telles et al.). However, the lack of consensus on diagnosis methods of tooth wear makes a comparison of prevalence results unreliable.

There is a hypothesis that these characteristics may be associated with restoration failures because occlusal overload may generate abnormal mechanical stress (Batistella et al., 2018). The results of the present study showed that there was no statistically significant difference in the distribution of fractured crowns between individuals with and without chronic tooth wear. These data become relevant since there are a large number of articles related to the rehabilitation of tooth wear. Specifically, only a few such reports were designed as long-term studies, which are considered to provide the strongest scientific evidence (Johansson et al.; Batistella et al.).

There were more posterior teeth (premolars and molars) restored with total ceramic crowns in this study; these data were homogeneous to other clinical studies developed (Janus et al., 2006; Kassem et al., 2010) and there was no statistically significant difference in the distribution of fractured crown presence of fracture between the tooth localization variable. However, 90 $\%$ of the evaluated fractures were in posterior teeth. The risk of fracture of these teeth should be carefully evaluated as they are substantially subjected to stress under continuous application of mechanical loads and progressive degradation may lead to crack propagation which will ultimately determine the restoration failure. However, the complexity of the buccal environment and the varied topography of the surfaces of the restorations make it difficult to precisely define the magnitude and manner in which the stresses are involved in the clinical fracture (Ozcan \& Niedermeier, 2002). Other factors than the inherent mechanics of material strength must be considered when crowns are cemented in the teeth, among them the operator's ability, the tooth condition, configuration of the preparations, correct occlusal adjustment, the cement used, the thickness and the presence of restorative material defects. In addition, laboratory tests fail to evaluate all of these variables (Pjetursson et al.).

High-strength ceramics were initially veneered with feldspathic porcelain; however, chipping of the veneering porcelain has been reported (de Lima et al., 2015). Despite this, the low incidence of fractures among the analyzed ceramic systems is in line with the assertions that the fracture strength of ceramic crowns may be based on a correct diagnosis and treatment plan (Segal et al., 2001). One of the ceramic systems evaluated (metal-ceramic) is considered as the standard of excellence for clinical follow-up analysis and its performance was similar to the metal-free systems (Feldspathic ceramic and In-Ceram Alumina). There are still other important features to be considered in survival tests of ceramic crowns in individuals with signs of dental wear. The loads generally used in the tests are necessarily high loads (1500 to $5000 \mathrm{~N}$ ) compared to that occurring during masticatory load (5 to $364 \mathrm{~N}$ ) or maximal force during bruxism (216 to 890 $\mathrm{N}$ ), resulting in porcelain fracture in several fragments. According to Raposo et al. (2009), there are only two fragments which can generally be observed. Thus, knowledge of the properties and the correct indication of the new restorative alternatives must be fundamental to obtain the desired result (Overmeer et al., 2016).

In this study, a higher occurrence of fractures was identified among ceramic crowns in pulp vitality teeth with a statistically significant difference. Most studies investigating fractures in prosthetic crowns showed the opposite, meaning there was a similar or higher incidence of fractures in non-vital teeth (De Backer et al., 2007; van Dijken \& Hasselrot, 2010). Results for vital and non-vital teeth might differ, although respective differences have not been consistently found (Reitemeier et al., 2013). One possible explanation would be to perform a more conservative dental preparation in order to guarantee a less traumatic intervention to the tooth and thus preserve pulp vitality. Thus, the thickness of the restorative material may be limited. In general, there are specific recommendations of minimum thickness that offer specific mechanical strength for each ceramic system (Pjetursson et al.).

In a general analysis, 10 occurrences were observed regarding the incidence of catastrophic fractures among the evaluated ceramic systems. A clinical performance from 23 days to 120 months interval was $91.1 \%$. These results are in agreement with the findings of a meta-analysis by Pjetursson et al., who observed an estimated $93.3 \%$ clinical performance for 
LOPES, G. R. S.; VIANA, A. A. F.; DINIZ, V.; MATOS, J. D. M.; ANDRADE, V. C.; BOTTINO, M. A, NISHIOKA, R. S.; CHIARELLI, F. M.; FEITOSA, A. C. R. \& GUERRA, S. M. G. Incidence of fracture in single ceramic crowns in patients with chronic tooth wear: a clinical follow-up. Int. J. Odontostomat., 15(1):102-110, 2021.

all aesthetic crowns in function for five years. This corroborated the results of Della Bona \& Kelly, in which the available evidence indicates high effectiveness of the ceramic systems used for reconstructions in total unit crowns. In this study, there was a statistically significant difference for the survival time variable, which showed most fractures occurring in the first few years. This result is in agreement with others, since veneer chipping or loss of the prosthetic crown may occur in the first few years. As a limitation of the study, it is impossible to determine the cause and to guarantee that the confounding factors will be equally distributed between the groups, since it is a retrospective study with cross-sectional design.

\section{CONCLUSIONS}

A low incidence of catastrophic fractures was observed among the total ceramic crowns studied, and therefore the evaluated ceramic systems can be considered as alternatives of restorative material, even in individuals with clinical characteristics suggestive of chronic tooth wear. Moreover, prosthetic crown fractures of the evaluated systems occur more frequently in the first few years.

LOPES, G. R. S.; VIANA, A. A. F.; DINIZ, V.; MATOS, J. D. M.; ANDRADE, V. C.; BOTTINO, M. A, NISHIOKA, R. S.; CHIARELLI, F. M.; FEITOSA, A. C. R. \& GUERRA, S. M. G. Incidencia de fractura en coronas cerámicas únicas en pacientes con desgaste dental crónico: Un seguimiento clínico. Int. J. Odontostomat., 15(1):102-110, 2021.

RESUMEN: El objetivo de este estudio fue identificar la incidencia de fracturas en coronas individuales colocadas en individuos con desgaste dental crónico. La selección de la muestra se realizó en base a la evaluación de 218 registros de pacientes rehabilitados con coronas individuales colocadas entre 1999 y 2009 por el mismo profesional de una clínica privada. Después de analizar los criterios de exclusión, se incluyeron 43 individuos (18 hombres y 25 mujeres) y un total de 112 coronas individuales distribuidas en ambas mandíbulas. Este estudio evaluó coronas hechas de tres sistemas cerámicos: 34 de cerámica totalmente feldespática, 38 de cerámica de metal con un núcleo de aleación electropositiva de oro y 40 de alúmina enceram. El análisis de la fotografía intraoral adoptó un método de diagnóstico del desgaste dental de acuerdo con las variaciones morfológicas de los dientes. De las 112 coronas evaluadas, 47 se colocaron en hombres y 65 en mujeres, con edades comprendidas entre 21 y 74 años (media de 27,5 años). Con respecto a las coronas individuales, las variables género $(p$
$=0,83)$, presencia de desgaste dental crónico $(p=0,91)$, sistema cerámico $(p=0,24)$ y ubicación de la corona $(p=$ $0,86)$ no presentaron una diferencia estadísticamente significativa. Sin embargo, las variables vitalidad pulpar $(p=0.04)$ y tiempo de supervivencia $(p=0.01)$ presentaron una diferencia estadísticamente significativa. Los sistemas cerámicos evaluados pueden considerarse como alternativas de material restaurador, incluso en individuos con características clínicas que sugieren desgaste dental crónico.

PALABRAS CLAVE: corona del diente, prostodoncia, factores de riesgo.

\section{REFERENCES}

Bayne, S. C. Dental restorations for oral rehabilitation - testing of laboratory properties versus clinical performance for clinical decision making. J. Oral Rehabil., 34(12):921-32, 2007.

Campos, T. M. B.; Ramos, N. C.; Machado, J. P. B.; Bottino, M. A.; Souza, R. O. A. \& Melo, R. M. A new silica-infiltrated Y-TZP obtained by the sol-gel method. J. Dent., 48:55-61, 2016.

Campos, T. M. B.; Ramos, N. C.; Matos, J. D. M.; Thim, G. P.; Souza, R. O. A.; Bottino, M. A.; Valandro, L. F. \& Melo, R. M. Silica infiltration in partially stabilized zirconia: Effect of hydrothermal aging on mechanical properties. J. Mech. Behav. Biomed. Mater., 109:103774, 2020.

Cehreli, M. C.; Kokat, A. M.; Ozpay, C.; Karasoy, D. \& Akca, K. A randomized controlled clinical trial of feldspathic versus glassinfiltrated alumina all-ceramic crowns: a 3-year follow-up. Int. J. Prosthodont., 24(1):77-84, 2011.

De Backer, H.; Van Maele, G.; Decock, V. \& Van den Berghe, L. Long-term survival of complete crowns, fixed dental prostheses, and cantilever fixed dental prostheses with posts and cores on root canal-treated teeth. Int. J. Prosthodont., 20(3):229-34, 2007.

de Lima, E.; Meira, J. B. C.; Özcan, M. \& Cesar, P. F. Chipping of veneering ceramics in zirconium dioxide fixed dental prosthesis. Curr. Oral Health Rep., 2:169-73, 2015.

de Matos, J. D. M.; Nakano, L. J. N.; Bottino, M. A.; de Jesus, R. H. \& Maciel, L. C. Considerações atuais quanto as cerâmicas odontológicas e seus respectivos sistemas de união. Rev. Bras. Odontol., 77(1):1-5, 2020.

de Souza Melo, G.; Batistella, E. A.; Bertazzo-Silveira, E.; Gonçalves, T. M. S. V.; de Souza, B. D. M.; Porporatti, A. L.; Flores-Mir, C. \& De Luca Canto, G. Association of sleep bruxism with ceramic restoration failure: A systematic review and meta-analysis. J. Prosthet. Dent.,119(3):354-62, 2018.

Della Bona, A. \& Kelly, J. R. A variety of patient factors may influence porcelain veneer survival over a 10 -year period. J. Evid. Based Dent. Pract., 10(1):35-6, 2010.

Erpenstein, H.; Borchard, R. \& Kerschbaum, T. Long-term clinical results of galvano-ceramic and glass-ceramic individual crowns. J. Prosthet. Dent., 83(5):530-4, 2000.

Ferrario, V. F.; Sforza, C.; Serrao, G.; Dellavia, C. \& Tartaglia, G. M. Single tooth bite forces in healthy young adults. J. Oral Rehabil., 31(1):18-22, 2004.

Janus, C. E.; Unger, J. W. \& Best, A. M. Survival analysis of complete veneer crowns vs. multisurface restorations: a dental school patient population. J. Dent. Educ., 70(10):1098-104, 2006.

Johansson, A.; Johansson, A. K.; Omar, R. \& Carlsson, G .E. Rehabilitation of the worn dentition. J. Oral Rehabil., 35(7):54866, 2008. 
LOPES, G. R. S.; VIANA, A. A. F.; DINIZ, V.; MATOS, J. D. M.; ANDRADE, V. C.; BOTTINO, M. A, NISHIOKA, R. S.; CHIARELLI, F. M.; FEITOSA, A. C. R. \& GUERRA, S. M. G. Incidence of fracture in single ceramic crowns in patients with chronic tooth wear: a clinical follow-up. Int. J. Odontostomat., 15(1):102-110, 2021.

Kassem, A. S.; Atta, O. \& El-Mowafy, O. Survival rates of porcelain molar crowns-an update. Int. J. Prosthodont., 23(1):60-2, 2010.

Lee, J. H.; Lee, J. B.; Park, J. I.; Choi, S. H. \& Kim, Y. T. Mechanical complication rates and optimal horizontal distance of the most distally positioned implant-supported single crowns in the posterior region: a study with a mean follow-up of 3 years. J. Prosthodont., 24(7):517-24, 2015.

Li, J.; Fan, W.; Lu, Y.; Xuan, D.; Liu, Z.; Huang, S. \& Zhang, J. A survey on the prevalence and risk indicators of erosive tooth wear among adolescents in Guangzhou, South China. J. Oral Rehabil., 46(6):493-502, 2019.

Machado, N. A. G.; Fonseca, R. B.; Branco, C. A.; Barbosa, G. A. S.; Fernandes Neto, A. J. \& Soares, C. J. Dental wear caused by association between bruxism and gastroesophageal reflux disease: a rehabilitation report. J. Appl. Oral Sci., 15(4):327-33, 2007.

Marklund, S.; Bergman, B.; Hedlund, S. O. \& Nilson, H. An intraindividual clinical comparison of two metal-ceramic systems: a 5-year prospective study. Int. J. Prosthodont., 16(1):70-3, 2003.

Overmeer, J.; Narby, B.; Hjalmarsson, L.; Arnrup, K. \& Eliasson, A. A retrospective multicenter study comparing metal-ceramic and composite single crowns performed in public general dentistry: 5-year results. Acta Biomater. Odontol. Scand., 2(1):43-8, 2016.

Ozcan, M. \& Niedermeier, W. Clinical study on the reasons for and location of failures of metal-ceramic restorations and survival of repairs. Int. J. Prosthodont., 15(3):299-302, 2002.

Peixoto, N. M.; Melo de-Matos, J. D.; Andrade, V. C.; Bottino, M. A. \& Zogheib, L. V. Evaluation of union resistance of orthodontic bracelets fixed to lithium dissylate ceramic. Int. J. Odontostomat., 13(2):207-18, 2019.

Pjetursson, B. E.; Sailer, I.; Zwahlen, M. \& Hämmerle, C. H. F. A systematic review of the survival and complication rates of allceramic and metal-ceramic reconstructions after an observation period of at least 3 years. Part I: Single crowns. Clin. Oral Implants Res., 18 Suppl. 3:73-85, 2007.

Raposo, L. H. A.; Neiva, N. A.; da Silva, G. R.; Carlo, H. L.; da Mota, A. S.; do Prado, C. J. \& Soares, C. J. Ceramic restoration repair: report of two cases. J. Appl. Oral Sci., 17(2):140-4, 2009.

Reitemeier, B.; Hänsel, K.; Kastner, C.; Weber, A. \& Walter, M. H. A prospective 10-year study of metal ceramic single crowns and fixed dental prosthesis retainers in private practice settings. $J$. Prosthet. Dent., 109(3):149-55, 2013.

Schwarz, S.; Schröder, C.; Hassel, A.; Bömicke, W. \& Rammelsberg, $P$. Survival and chipping of zirconia-based and metal-ceramic implant-supported single crowns. Clin. Implant Dent. Relat. Res., 14 Suppl. 1:e119-25, 2012.

Segal, B. S. Retrospective assessment of 546 all-ceramic anterior and posterior crowns in a general practice. J. Prosthet. Dent., 85(6):544-50, 2001

Telles, D.; Pegoraro, L. F. \& Pereira, J. C. Incidence of noncarious cervical lesions and their relation to the presence of wear facets. J. Esthet. Restor. Dent., 18(4):178-83, 2006.

van Dijken, J. W. V. \& Hasselrot, L. A prospective 15-year evaluation of extensive dentin-enamel-bonded pressed ceramic coverages. Dent. Mater., 26(9):929-39, 2010.

van't Spijker, A.; Kreulen, C. M. \& Creugers, N. H. J. Attrition, occlusion, (dys)function, and intervention: a systematic review. Clin. Oral Implants Res., 18 Suppl. 3:117-26, 2007.

Verrett, R. G. Analyzing the etiology of an extremely worn dentition. J. Prosthodont., 10(4):224-33, 2001.

Young, W. G. The oral medicine of tooth wear. Aust. Dent. J., 46(4):236-50, 2001

Zhang, J.; Du, Y.; Wei, Z.; Tai, B.; Jiang, H. \& Du, M. The prevalence and risk indicators of tooth wear in 12- and 15-year-old adolescents in Central China. BMC Oral Health, 15:120, 2015.
Corresponding author:

Jefferson David Melo de Matos

São Paulo State University (Unesp)

Institute of Science and Technology Department of

Restorative Dentistry

Av. Engenheiro Francisco José Longo, 622 - Apt 162

Jardim São Dimas

São José dos Campos

São Paulo

Zip Code: 12245-000

BRAZIL

E-mail: guilherme.scalzer@unesp.br matosjefferson19@gmail.com 